\title{
A poética da resistência nos poemas sobre a Guerrilha do Araguaia: 0 corpus do jornal Resistência
}

\author{
The poetics of resistance in the poems about the Guerrillha do Araguaia: the corpus \\ of the newspaper Resistência \\ La poética de la resistencia en los poemas sobre la Guerrilha do Araguaia: el corpus \\ del periódico Resistencia
}

\section{Ivania Melo}

ivanpmelo2016@gmail.com

Universidade Federal do Pará - UFPA, Brasil

Tânia Sarmento-Pantoja

t.sarmentopantoja@gmail.com

Universidade de Lisboa, Portugal

Recepção: 17 Maio 2020

Aprovação: 25 Junho 2020

Publicação: 01 Diciembre 2020

Cita sugerida: Melo, I. y Sarmento-Pantoja, T. (2020). A poética da resistência nos poemas sobre a Guerrilha do Araguaia: o corpus do jornal Resistência. Aletheia, 11(21), e064. https://doi.org/10.24215/18533701e064
Resumo: Este artigo analisa dois poemas que tem como tema a Guerrilha do Araguaia, que são parte de um conjunto de textos poéticos publicados no jornal Resistência, em fevereiro de 1979, no Brasil. A análise considerou os aspectos históricos relacionados ao tema e a constatação da questão central: quais elementos presentes indicam o enquadramento dos poemas em uma poética da resistência.

Palavras-chave: Guerrilha do Araguaia, Resistência, Poema, Memória.

Abstract: This article analyzes two poems whose theme is the Guerrilha do Araguaia, which are part of a set of poetic texts published in the Resistencia newspaper, in February 1979, in Brazil. The analysis considered the historical aspects related to the theme and the verification of the central question: which elements present indicate the framing of the poems in a poetics of resistance.

Keywords: Guerrilha do Araguaia, Resistance, Poem, Memory.

Resumen: Este artículo analiza dos poemas que tienen como tema la Guerrilla del Araguaia, que integran un conjunto de textos poéticos publicados en el periódico Resistencia, en febrero de 1979, en Brasil. El análisis consideró los aspectos históricos relacionados al tema y la constatación de la cuestión central: qué elementos presentes en los poemas permiten ubicarlos dentro de una poética de la resistencia.

Palabras clave: Guerrilha do Araguaia, Resistencia, Poema, Memoria.

Dedicamos este artigo ao jornalista e escritor Luiz Maklouf Carvalho que, de modo hábil, soube jogar "luz nos fatos". 


\section{INTRODUÇÃO}

As críticas ao governo ditatorial, que comandou o Brasil no período de 1964 a 1985, aconteceram de várias formas, entre elas estão as manifestações artísticas e jornalísticas, que apesar da censura, nunca deixaram de ser proferidas. Os registros dessa oposição podem ser encontrados em livros, poemas, peças, músicas, charges, artigos, entrevistas, matérias publicadas, principalmente na imprensa chamada "alternativa", também conhecida como "nanica", "popular", "do povo", "democrática" e "combativa" - tal como classificada nas páginas do jornal Resistência, periódico integrado ao grupo dos alternativos, no qual buscamos o objeto deste estudo.

O Resistência foi um veículo jornalístico pertencente à Sociedade Paraense de Defesa dos Direitos Humanos (SDDH), uma entidade civil sem fins lucrativos, com fundo social baseado em contribuições dos sócios, doações, legados e arrecadações eventuais, fundada oficialmente no dia 08 de agosto de 1977, "com sede e foro na cidade de Belém, Estado do Pará”, no norte do Brasil (Amazônia brasileira), tendo como objetivo a "proteção e defesa dos direitos da pessoa humana" (SDDH, 1977) ${ }^{1}$. O jornal circulou durante a vigência da ditadura civil e militar brasileira (1964-1985). Sua periodicidade inicia no final da década de 1970 e vai até a metade da década de 80 , portanto, no período da "Abertura", em que teve início a redemocratização. Por conta do contexto repressivo da época e da política editorial adotada os seus responsáveis e colaboradores sofreram perseguições de variada ordem, dentre as quais se destacam a apreensão e o boicote ao jornal, por parte dos órgãos de repressão do estado ditatorial, que provocaram atrasos e até interrupções em suas edições regulares $^{2}$. Nesse sentido, a título de um preâmbulo inicial, afirmamos que o presente estudo se justifica em função de que os jornais alternativos e com clara política editorial de combate ao governo ditatorial, que circularam no Brasil nesse período, ainda constituem um material rico em informaçóes e precisa ser mais explorado.

Considerando esses aspectos, o resultado da pesquisa (realizada de abril a dezembro de 2016) que ora apresentamos baseou-se em um corpus formado por quarenta e seis exemplares do jornal Resistência, que abrangem o período de fevereiro de 1978 a dezembro de 1984. Esse corpus pertence ao Arquivo privado Alexandre Cunha, localizado no Laboratório de Antropologia Arthur Napoleão Figueiredo, anexo do Instituto de Filosofia e Ciências Humanas (IFCH), na Universidade Federal do Pará (UFPA), localizada no norte do Brasil. Está em meio físico e organizado por ordem cronológica.

A análise que pretendemos apresentar compreende um conjunto de poemas publicados no referido jornal. Tais produções são encontradas na edição de fevereiro de 1979 e apresentadas aos seus leitores como "Os poemas da Guerrilha do Araguaia” (Carvalho, 1979b, p. 24). Consistem em oito textos supostamente escritos por guerrilheiros - composições que também integram parte do folheto Primeiras Cantigas do Araguaia, de Libério de Campos. Atribuímos à condição de "suposta autoria" em razão de que a polifonia presente nesses poemas, as semelhanças e espelhamentos com outros materiais, presentes em outras fontes, bem como a ausência de dados contundentes acerca da existência de seu autor, contradiz a assinatura no folheto como sendo de apenas um responsável. Parece-nos que Libério de Campos é antes o disfarce de alguém que foi, sobretudo, o responsável por reunir esses textos e atuar como editor.

Vale ressaltar ainda que embora o foco deste trabalho seja a produção literária relacionada ao movimento guerrilheiro, outros materiais, incluindo textos em prosa, se fazem presentes no mesmo periódico. Há nos poemas expressões de lutas, individuais ou coletivas, por direitos e liberdades, que encontram no jornal Resistência o suporte e a visibilidade negados em outros espaços. Ademais, independente de quem os escreveu, neste estudo, os poemas serão observados à luz do contexto de produção, em particular em função dos fortes elos temáticos com a guerrilha. Essa condição nos leva a pontuar a análise com base no paradigma da poesia de resistência.

Por serem produções inseridas em um contexto de militância política, a abordagem adotada neste estudo é a da análise materialista para a constatação da questão central, ou seja, quais elementos presentes no conjunto indicam o enquadramento em uma poética da resistência. 


\section{Notícias da RESistênCIA No Jornal ResistênCia: A guerrilha do Araguaia}

Figura 1 - Resistência (Edição Extra No 3), 11-1979

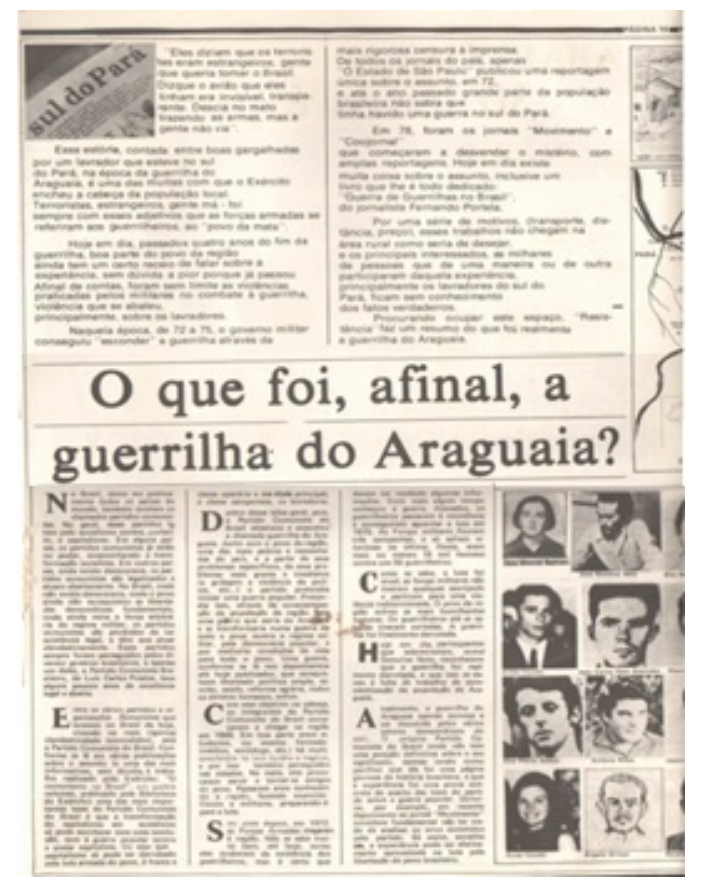

Fonte: Arquivo privado Alexandre Cunha

As notícias e materiais que permeiam a presença da Guerrilha do Araguaia nas páginas do jornal Resistência estão profundamente relacionados às perseguições sofridas pelos editores. Nesse percurso, a história desse periódico não se limita a ser o caminho de um jornal pró-resistência; é também a trajetória de como o alternativo lutou contra a repressão. As perseguições, contudo, não foram motivadas somente pelas notícias vinculadas à guerrilha, mas a todo o status quo envolvido na política editorial do Resistência, a exemplo da primeira crise financeira que atingiu o impresso motivada pela publicação de depoimentos sobre torturas. Em julho de 1978 o jornal fez referência à violência sofrida por membros da SDDH, mas somente em agosto do mesmo ano, na edição $\mathrm{N}^{\circ} 5$, especial de aniversário de um ano da Sociedade, a matéria veio a público completa e detalhada.

Antes mesmo de sair da gráfica, quatro mil e quinhentos, dos cinco mil exemplares impressos, foram apreendidos por agentes da Polícia Federal em cumprimento à ordem do Ministério da Justiça. A edição apresentou em dez páginas os depoimentos de Humberto Rocha Cunha, Izabel Cunha, Paulo Fontelles de Lima e Hecilda Veiga, quatro paraenses, ex-presos políticos que relataram as torturas sofridas nos anos 71/72, inclusive os dois últimos dentro do prédio do Ministério do Exército em Brasília ${ }^{3}$. Os responsáveis pela publicação, entre eles o editor-chefe, Luiz Maklouf Carvalho, foram arrolados pelo Inquérito Policial Militar (IPM) 78/78, instaurado pela Delegacia Regional da Polícia Federal, com base no artigo 16, parágrafo $2^{\circ}$, da Lei de Segurança Nacional (LSN).

A mesma edição publicou uma matéria "Especial" com o título "História da Guerrilha do Araguaia", uma transcrição da reportagem divulgada pelo semanário Movimento, periódico que circulou em São Paulo no mesmo período que o Resistência. Seis páginas com entrevistas e relatos de personalidades do Exército, policiais da região, membros da população local, ex-integrantes do movimento, membros do clero local e indígenas pertencentes à etnia Suruí. 
Mas, mesmo com dificuldades o jornal seguia na batalha democrática-popular que, nas palavras de seu editor era: "uma luta de continuada resistência" (Carvalho, 1979c, p. 2). Sem recuar diante das perseguiçóes, os temas "tortura" e "guerrilha" igualmente se fizeram presentes em outras edições, como a de setembro de 1978 que abriu espaço ao protesto de José Genoino Neto, ex-guerrilheiro, "contra as distorções que a revista Veja publicou" (p. 23) sobre o movimento ocorrido no norte do Brasil; a de fevereiro de 1979 que, além de publicar oito poemas reproduzidos do folheto As primeiras cantigas do Araguaia, divulgou a entrevista com o médico Benigno Girão Barroso (pp.18-19), pai da estudante Jana Moroni Barroso (Cristina), que se mudou para o sudeste do Pará em abril de 1971 e está desaparecida desde 8 de fevereiro de 1974 (Dossiê Ditadura, 2009, p. 536).

Em novembro de 1979, novamente o assunto retorna ao Resistência com o título: "O que foi, afinal, a Guerrilha do Araguaia?". Trata-se de um resumo sobre o movimento com fotos de alguns integrantes e a divulgação do chamado "Programa dos 27 pontos", um projeto político que "sintetizou os desejos e aspirações mais sentidos do povo" formulados com a ajuda da União pela Liberdade e pelos Direitos do Povo (ULDP), organização criada pelos integrantes do movimento na região (pp. 10-11). Apesar dos depoimentos sobre as torturas terem provocado perseguições, apreensões, interrogatórios, invasões, inquéritos policiais e interrupção das impressões do jornal, o retorno das edições que iniciam a segunda fase do periódico foi marcado por outra manchete "bomba": "Guerrilha do Araguaia: granada do Exército mata e mutila lavradores" (Carvalho, 1980a, pp. 18-19).

$\mathrm{Na}$ Edição No 19, de dezembro de 1980 o tema é novamente manchete: "Familiares dos guerrilheiros descobrem sobrevivente na região". São quatro páginas que relatam a ida de parentes dos desaparecidos até a região onde ocorreram os conflitos. Luiz Maklouf Carvalho, representante do Resistência, acompanhou a caravana que esteve "Na trilha do "povo da mata" (1980b, pp. 5-8). Outra notícia, em maio de 1983, registra o retorno de José Genoino Neto, deputado federal e "ex-guerrilheiro", ao Araguaia 11 anos depois, acompanhado por mais 12 deputados federais, em comitiva interpartidária (Partido do Movimento Democrático Brasileiro - PMDB; Partido dos Trabalhadores - PT; Partido Democrático Trabalhista PDT) que visitou o sul do Pará e pode avaliar as proporções de outros choques, mas desta vez se tratava de conflitos de terras naquela região (Vital, p. 13).

\section{“Os poemas da guerrilha do AraguaiA": as Fontes E UM Problema de AUtoria}

A Guerrilha do Araguaia foi um movimento revolucionário ocorrido no norte do Brasil durante a primeira metade da década de 1970. Segundo o Dossiê Ditadura: Mortos e Desaparecidos Políticos no Brasil (1964-1985) (2009, p. 403), os guerrilheiros começaram a chegar à região desde 1966. Estabeleceram-se em uma área estratégica localizada entre os estados do Pará, Maranhão e Goiás (atual Tocantins), conhecida como Bico do papagaio. Durante a repressão as Forças Armadas mobilizaram cerca de sete mil militares contra setenta e três guerrilheiros divididos em três destacamentos (A - Faveira; B Gameleira; e C - Caiano) $)^{4}$. De acordo com o Dossiê, todos os prisioneiros foram executados e alguns corpos decapitados e enterrados em bases militares (p. 403). Na linguagem dos militares e seus guias a expressão "bico do papagaio" também era usada para indicar decapitação. O mateiro Sinésio Martins Ribeiro contou em depoimento: "A gente andava com saco de plástico grosso. Se acontecesse o que aconteceu, cortar o bico do papagaio e botar no saco, para levar a prova que matamos. $\mathrm{Na}$ guerra, não se falava em arrancar cabeça. A gente falava que era bico do papagaio" (Nossa, 2012, p. 177).

Em de 12 de agosto de 2014, a Comissão Nacional da Verdade (CNV) realizou audiência pública para apresentar os números resultantes do confronto. O relatório da $\mathrm{CNV}$ indicou sessenta e quatro mortos identificados (2014,pp. 714-715) e, aproximadamente, cinquenta desaparecidos. Para exterminar a guerrilha as Forças Armadas planejaram e executaram várias operações militares na área, dentre as quais as nomeadas: 
"Carajás”, "Mesopotâmia”, “Axixá”, "Sucuri” "Peixe I”, "Peixe II”, "Peixe III” e "Peixe IV”. As operações envolviam ações de espionagem, infiltração, delação, combate, aprisionamento e extermínio.

O tema "Guerrilha do Araguaia" permaneceu longe das páginas dos periódicos durante muito tempo. Mesmo após o fim da censura prévia, em 1978, poucos jornais ousaram publicar matérias referentes à luta armada do norte do país. Os jornais Movimento, Coojornal e Resistência foram os que romperam o silêncio. O grupo revolucionário que atuou na região do Araguaia criou a União pela Liberdade e pelos Direitos do Povo (ULDP), responsável pelo lançamento do programa "Em Defesa do Povo Pobre". Sobre este assunto, Elza Monnerat disse ao jornal Movimento (matéria transcrita pelo Resistência, No 5, de agosto de 1978) que se tratava de uma "síntese das principais reivindicações da região [...] mais ou menos as mesmas [...] da maior parte das zonas camponesas do país” (p. 13). Contou também que durante a guerrilha surgiram poetas e músicos entre os militantes e que compuseram o Hino dos guerrilheiros; dois poemas em estilo de literatura de cordel; e, várias poesias dedicadas a Helenira Rezende de Sousa Nazareth (Fátima) ${ }^{5}$ e João Carlos Haas Sobrinho (Juca) ${ }^{6}$.

Em fevereiro de 1979 o jornal Resistência publicou, com exclusividade, oito poemas da Guerrilha do Araguaia: "Cantar é preciso"; "Verso \& Reverso"; "Canção das Forças Guerrilheiras do Araguaia”; "Eh Marabá"; "O Finado Joaquim"; "O início"; "Canto de amor aos guerrilheiros do Araguaia"; e "Poema do Soldado Morto" (Carvalho, 1979b, p. 24), supostamente escritos por componentes do grupo. Conforme já indicamos esses poemas também fazem parte de folheto mimeografado, contendo quarenta e três páginas, intitulado Primeiras Cantigas do Araguaia, de Libério de Campos - a versão online recebeu mais duas poesias entregues por um ex-exilado na Suécia: "A Helenira Rezende" e alguns fragmentos de "Escucha la voz del Araguaia". Mais poemas do folheto também ganharam espaço em outras produções, como em Guerrilha do Araguaia, organizado por Adalberto Monteiro (2005), são: "Abril”, "Poema para Helenira”, "Quelé" e "Canção da F.G.A.” (pp. 177-184).

Figura 2 - Resistência (No 9), 02-1979

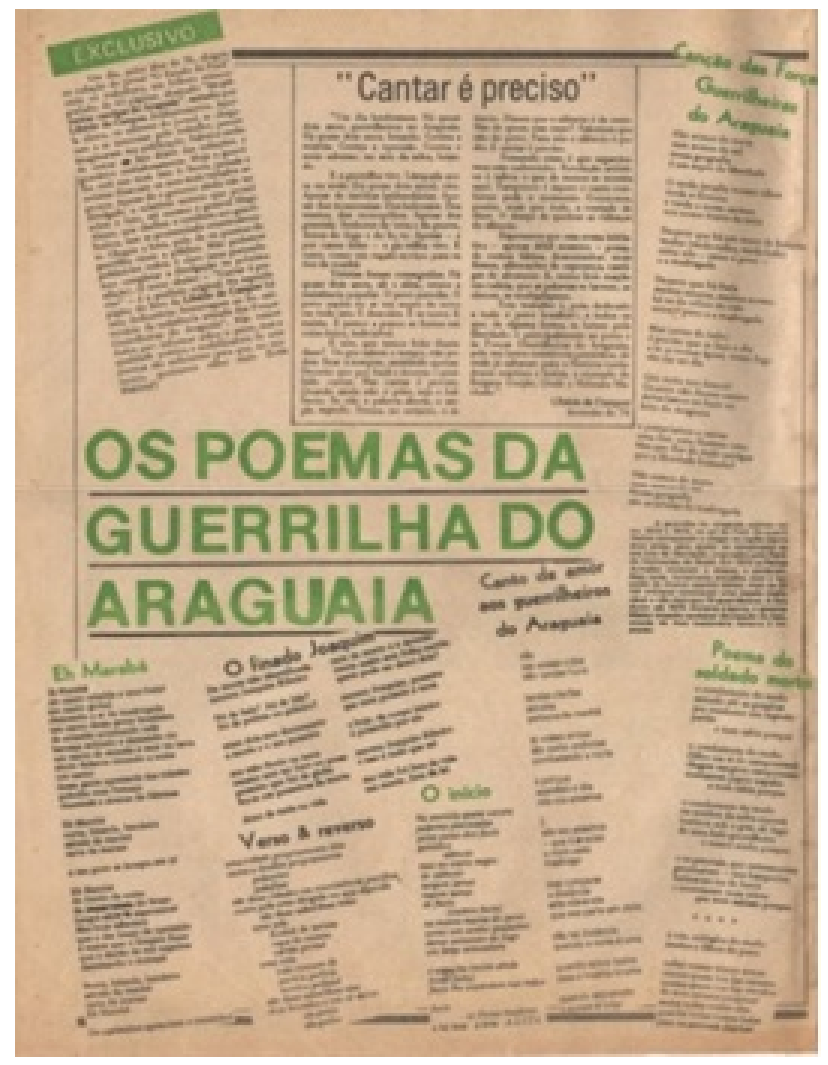

Fonte: Arquivo privado Alexandre Cunha 
Luiz Maklouf Carvalho explica, em nota divulgada na mesma página do jornal onde foram publicados os poemas da guerrilha, que a dedicatória no folheto Primeiras Cantigas do Araguaia indica ser uma produção em "homenagem ao $2^{\circ}$ aniversário [1974] da resistência armada das Forças Guerrilheiras do Araguaia” (Campos citado em Carvalho, 1979a, p. 24). Segundo o relato do próprio editor, em 1976 o material foi entregue na redação de O Estado do Pará. Sem a possibilidade de publicação permaneceu longe do conhecimento público até 1979, quando o jornal Resistência o divulgou parcialmente. Sobre o autor, Maklouf Carvalho, responsável pela obra, revelou não haver dados. Segundo a apresentação disponível na versão eletrônica do folheto: "Libério de Campos pode ser uma alusão dos autores aos objetivos de sua luta - 'Liberdade-Camponeses'" (Familiares de mortos e desaparecidos na guerrilha do Araguaia, 1980, p. 4).

Realmente não existe entre os componentes do movimento guerrilheiro do Araguaia ninguém com esta identificação, nem como "nome" ou "codinome". A referência mais próxima é a do militante conhecido como "Joca", ou Líbero Giancarlo Castiglia -italiano; filho de ativistas (mãe afiliada ao Partido Comunista Italiano e pai ao Partido Socialista); membro do Partido Comunista do Brasil (PCdoB); após 1964 passou a viver na clandestinidade; realizou cursos de capacitação política e militar na China e na Albânia; amigo de André Grabois, chegou ao Sudeste do Pará no final de 1967 junto com Maurício Grabois e Elza Monnerat, quando adotou o nome de João Bispo Ferreira da Silva, estabelecendo-se como comerciante na localidade de Faveira; integrou a Comissão Militar da guerrilha do Araguaia e está desaparecido desde o dia 25 de dezembro de 1973 (Dossiê Ditadura, 2009, pp. 520-521). Além da semelhança dos nomes, nada consta sobre ele ser o verdadeiro autor dos poemas supracitados.

Se por um lado não há comprovação definitiva de que foram os combatentes da guerrilha que escreveram os poemas de Primeiras Cantigas do Araguaia, por outro também não se pode provar o contrário. Tampouco é possível afirmar sem reservas que a autoria seja de Libério de Campos. Assim, considerando este argumento e a informação de Luiz Maklouf Carvalho, de que "a qualidade poética e mobilizadora de seus [versos] são suficientes para que [...] queiramos saber mais” (1979a, p. 24), somados à indicação no folheto disponibilizada em meio eletrônico que diz: "Quem as lê percebe que, de fato, foram feitas por pessoas muito íntimas da guerrilha" (Familiares de mortos e desaparecidos na guerrilha do Araguaia, 1980, p. 4), os poemas, independente de quem os escreveu, são considerados como objeto neste estudo por estarem relacionados à guerrilha do Araguaia e apresentarem uma poética da resistência.

Esta poética também está registrada em um documento cuja autenticidade gerou questionamento. Trata-se do Diário atribuído a Maurício Grabois - o comandante da guerrilha, também conhecido como "Mário, fazia uma espécie de diário, mas desapareceu desde aquele Natal [1973]. Na hipótese de os militares terem matado o velho Grabois, apreenderam os documentos." (Morais e Silva, 2012, p. 484). O historiador e pesquisador Hugo Studart conta que o

Diário do Velho Mário [...] chegou a Marabá no final da tarde de 25 de dezembro para ser encaminhado na primeira hora dia seguinte ao Centro de Informações do exercito, em Brasília. [...] Um capitão da área de informações [...] convocou cinco cabos e soldados para que se revezassem na tarefa de copiar o conteúdo à mão. $\mathrm{O}$ Diário original teria sido cremado. Restaram cópias datilografadas. (Studart, 2006, p. 45).

Leonencio Nossa informa que "o diário atribuído a Grabois foi publicado na internet pelo militar da reserva e pesquisador Carlos Azambuja, 33 anos após a morte de Zé Carlos.” (2012, p. 165). Osvaldo Bertolino (2011), escritor da biografia de Maurício, conta que recebeu, "anonimamente, trechos do que seriam as anotações do comandante militar da Guerrilha do Araguaia, mas, impossibilitado de verificar a veracidade do documento" optou por não usar as informações?.

Para este artigo, o que nos chama atenção são os elementos residuais presentes no Diário que intertextualizam com o material aqui analisado, isto é, a literatura apresentada referente à guerrilha e que, na visão de seu autor, expandia-se com o surgimento de poesias e hinos (Grabois, 2014, p. 112), material composto por: "Canção do Guerrilheiro do Araguaia", "Lutar", "12 de Abril”, música entoada no "terecô" 
e alguns "poemas da guerrilha". Entre as transcrições apresentadas pelo Diário está o hino das Forças Guerrilheiras do Araguaia (FGA): ${ }^{10}$

"Canção do Guerrilheiro do Araguaia”

Nas selvas sem fim da Amazônia

Vive e combate o guerrilheiro sem par

Valente e destemido

Sua bandeira fulgente é lutar

Tudo enfrenta com denodo

Para livrar da exploração

O povo pobre, a Terra amada

E construir nova Nação

Não dá trégua aos soldados

P'ra [sic] derrotar os generais

Emboscar, fustigar dia após dia

Atacar, sempre mais, sempre mais!

Sob o manto verde da floresta

Para as massas anseia paz e pão

Bem estar para os trabalhadores

Alegria para os jovens e instrução

Nada teme, jamais se abate

Afronta a bala a servir

Ama a vida, despreza a morte

E vai ao encontro do porvir

Está pronto p'ro[sic] combate

Em dia claro ou noite escura

Acabar, esmagar o imperialismo

Derrubar, liquidar a ditadura!

Da liberdade heróico[sic] defensor

Inimigo do regime militar

Quer terra p'ra todo lavrador

Feliz, viver e trabalhar

Lutador audaz do Araguaia

Rebelado no Sul do Pará

Junto ao povo, unido e armado

Na certa um dia vencerá

Sua tarefa gloriosa

Realiza com ardor

Avançar, empunhar todas as armas

Contra o inimigo opressor! (Grabois, 2014, p. 108-109)

Quanto à forma esta canção apresenta nove quadras com versos livres, variando entre 6 a 11 sílabas métricas. As rimas são externas, consoantes, a maioria rica e aguda, alternadas e seguindo o esquema rítmico: $\mathrm{ABCB}$, ou seja, a repetição de sons acontece somente no $2^{\circ}$ e no $4^{\circ}$ versos. A variação de sílabas nos versos rompe com a uniformidade métrica, rejeitando as regras de padronização.

Mesmo usando termos no singular como "guerrilheiro" e "inimigo opressor" o texto se encontra bastante pautado pela noção de "coletividade". Antônio Savino diz que "se o poeta vai exteriorizar sua linguagem estética, óbvio que esta criatividade será exatamente o 'ser' do poeta” e que a "linguagem é esta necessidade do homem dizer, fazer-se representar [...] através da poesia [...]" (1973, pp. 19-20). A letra do hino das Forças Guerrilheiras adota uma linguagem mais ética do que estética. É direta, sem rodeios e metáforas, expõe o interior de pelo menos dois corpos sociais: um é o grupo de combatentes que se encontra na clandestinidade - condição pertinente com o conteúdo do Diário de Maurício Grabois, para quem esse material "visa sempre exaltar o movimento guerrilheiro" (2014, p. 112); o outro é formado pelos habitantes de uma região marginal. Portanto, trata-se sempre de expor os anseios de um coletivo. Esta pode ser uma das possíveis explicações 
para o fato de vários textos que fazem parte desse corpus sobre a guerrilha do Araguaia não apresentarem assinatura de seus autores. Ou seja, o objetivo principal para a produção desse material não era promover talentos literários, mas divulgar o movimento e chamar atenção para os problemas sociais da região.

Trata-se de um material com traços épicos muito fortes, uma vez que apresenta matéria épica; uma voz poética em consonância com as figurações do herói épico moderno, disposto a resistir às forças sociais opressoras, ainda que para isso possa sofrer consequências devastadoras; no caso das canções apresenta ainda estrutura melódica e rítmica direcionada ao fortalecimento do clamor à luta, com as repetições fixadas nesse tema. Em função desses aspectos, trata-se de material alinhado com a expressão e a motivação da luta coletiva e nesse processo a voz poética se apresenta como representação de uma coletividade -em geral grupos privados de direitos e/ou explorados. Mesmo quando essa voz poética manifesta-se no singular ainda é uma voz épica, na medida em que convoca outras coletividades para a luta e as incentiva à união e à coragem. Outro aspecto a salientar é o teor rapsódico também presente, que reforça mais ainda a matéria épica.

A presença de vozes coletivas também é percebida em outros textos relacionados à luta armada no norte do Brasil. Pelo menos em alguns dos poemas da guerrilha. A musicalidade é redundante nessa produção: quando a forma musical não é referenciada no título, como em "Canção do Guerrilheiro do Araguaia”, "Canção das Forças Guerrilheiras do Araguaia"11 " "Canto de amor aos guerrilheiros do Araguaia" ${ }^{2}$, podemos encontrar a referência ao canto -como metáfora do clamor- na matéria épica, como em "Cantar é Preciso". As aspirações à resistência, em particular à luta combativa, também são percebidas tanto nos poemas da guerrilha como nos registros do Diário. Uma de suas anotaçóes, com data de 22 de junho de 1972, reflete a mesma confiança presente em alguns textos de Primeiras Cantigas do Araguaia:

Vem chovendo com frequiência $[s i c]$ e alguns dias se apresentam nublados como o de hoje. Ontem mesmo choveu à noite e na manhã de 19 caiu pesado "toró". Tudo isso nos causa embaraços. Mas não tem grande importância. Logo o sol brilhará intensamente, e seus raios se infiltrarão entre as árvores e seu calor animaráo habitante da selva. (Grabois, 2014, p. 16, grifo nosso).

"Noite”, “dia”, “madrugada”, “sol”, “estrela”, “manhã”, "luz”, “claro”, “escuro” são termos que também aparecem em algumas estrofes no corpus do jornal Resistência, conforme citamos a seguir:

"Canção das Forças Guerrilheiras do Araguaia"

[...]

que noite nos deterá?

Decerto não fizesse escuro

deitaríamos os fuzis no

leito do Araguaia

[...] (Campos citado em Carvalho, 1979b, p. 24)

"Canto de amor aos guerrilheiros do Araguaia"

não

nas vossas mãos

não tendes fuzis

tendes clarões

estrelas

pedaços de manhã

as vossas armas

são como archotes

combatendo a noite

[...] (Campos citado em Carvalho, 1979b, p. 24)

"O início"

$\mathrm{Na}$ avenida quase escura

palavras pisoteadas

pelas patas dos fuzis

gemidos

silêncio 


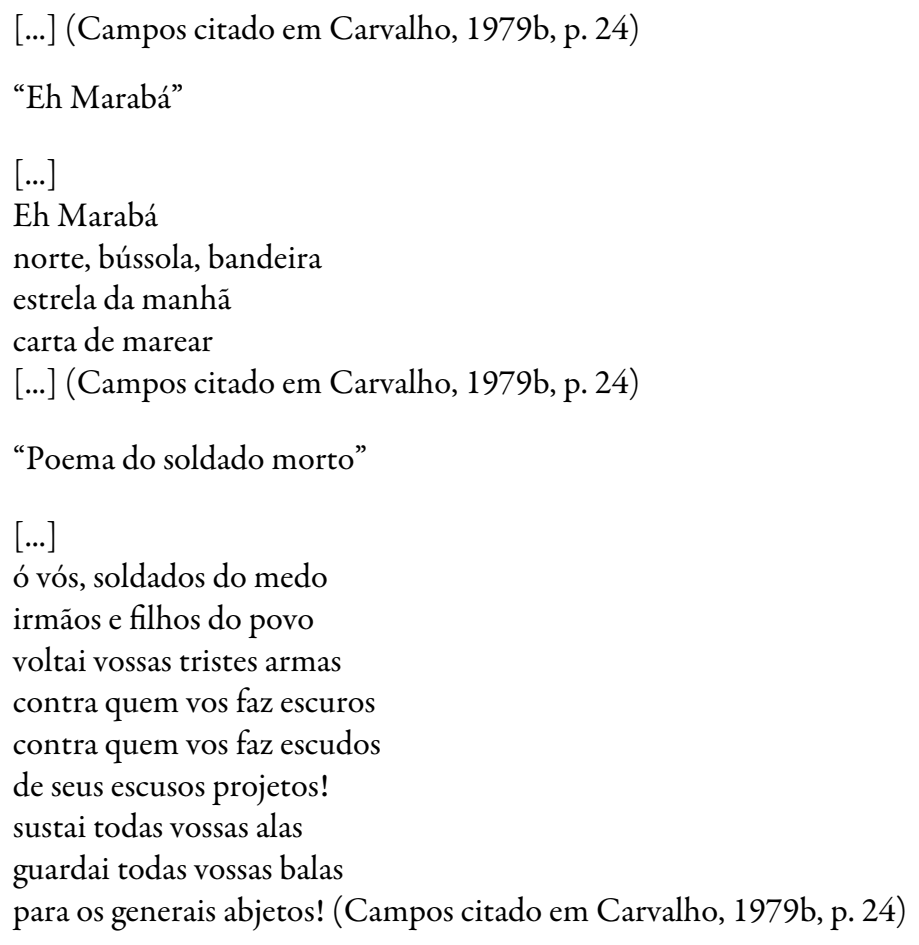

Analogias, metáforas, sinestesias, utilizadas para salientar o caráter épico, são recursos que aproximam a poesia sobre a guerrilha publicada pelo Resistência e o conteúdo do Diário de Grabois. Outro documento que chama a atenção pelo uso de elementos metafóricos semelhantes aos citados acima é a carta de Ciro Flávio Salazar de Oliveira (Flávio) ${ }^{13}$, escrita em 10 de setembro de 1972. Segue um fragmento:

Meus velhos, olhem para o horizonte. Os raios de esperança começam a nascer. Assim como o sol surge numa manha limpa e clara e vai aos poucos tomando corpo e esquentando a terra, também nós e a revolução estamos nascendo, tomando corpo e esquentaremos a nossa Pátria com a fogueira da guerra popular. ${ }^{14}$ (Morais e Silva, 2012, pp. 620-621)

Essas semelhanças entre os poemas da guerrilha e os relatos do Diário atribuído a Grabois reiteram a hipótese de que estes textos são oriundos do espaço da guerrilha, com possibilidade de terem sido produzidos no âmbito da experiência de campo desses guerrilheiros. Outra possibilidade é que vários desses poemas foram originariamente letras de canções, entoadas em reuniões de grupos e festejos locais, de alguma forma imersos ou relacionados à resistência. A propósito há relatos sobre a participação dos militantes em eventos promovidos por moradores da região envolvida na guerrilha. Por exemplo, há relato de que Lucio Petit da Silva (Beto) ${ }^{15}$ "fez vários poemas e literatura de cordel que eram recitados pelos camponeses da região e nas sessões de terecô” ${ }^{16}$ (Monteiro, 2005, p. 169). No Diário atribuído a Grabois consta que durante essas sessões cantava-se "interessante música":

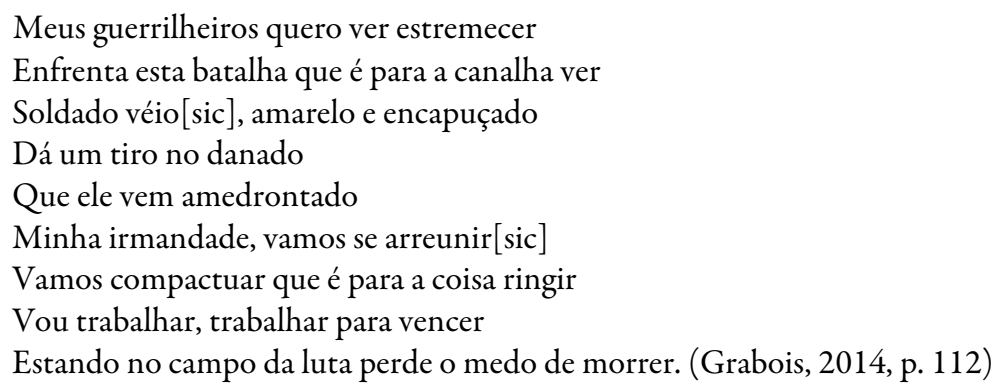

Essas canções são como hinos e fazem parte da mística nos encontros da militância. Outra canção, de autoria atribuída a Osvaldo Orlando da Costa (Osvaldão) ${ }^{17}$, está entre as anotações que seriam do comandante da guerrilha. Segue a letra: 
"Lutar"

Da Amazônia surge um grito varonil, lutar Aqui, às margens do Araguaia, ergue-se a bandeira Levanta-se o fuzil

Nós somos os lavradores, castanheiros e peões, tropeiros

Também somos garimpeiros e mariscadores, madeireiros, irmãos

Unidos a todo o povo explorado da Nação

Lutamos, lutamos contra a tirania pela liberdade, de fuzil na mão

As matas, bandeiras verdes, são a nossa proteção

Aqui, aqui nosso grito de guerra é a garantia da vitória na mão

Queremos a terra livre para viver e trabalhar

Lutar por um governo do povo

Abaixo a ditadura fascista militar

Com nossa terra livre

Haveremos de criar

Toda uma vida nova

De viver e lutar

Lutar é viver

Viver é trabalhar

Para construir

Um novo Brasil

Por esta terra forte há de ser nossa até morrer

Porque nos viu nascer (Grabois, 2014, p. 113)

Outro gênero bem aceito na região era a literatura de cordel, uma das formas mais simples para a divulgação do movimento às "massas da região" e que alcançou “imenso sucesso" (Grabois, 2014, p. 112). José Vieira $(\text { Zezinho })^{18}$, morador de São Domingos do Araguaia e filho de "Luizinho, agricultor recrutado pela guerrilha, [...] gravou na memória o 'romance' ${ }^{19}$-como no Araguaia são chamadas as poesias de cordel- que Beto [Lúcio Petit da Silva] escreveu e recitava à noite nos acampamentos na mata". Segue o material:

Eu que nunca fui poeta

Que nunca fui cantador

Agora vou contar a vida

De um homem trabalhador

Eu nasci não sei bem onde

Maranhão ou Ceará

Andei Piauí e Goiás

Rolando a deus-dará

Andei Norte, Nordeste

Viajando mais que a peste

Eu vim te encontrar

Aqui no Pará

Tinha uma casa formosa

Canteiro de alho e coentro

Muita fruteira plantada

No meu sítio lá no centro

Morando perto do posto

Deixei todo esse conforto

E me soquei pro mato adentro. (Nossa, 2012, pp. 167-168)

O mais recitado nas fontes consultadas é o "Romance da Libertação do Povo" ${ }^{20}$. Ele estava entre o material “distribuído em S. Domingos, Palestina e S. Geraldo", e fazia parte do que era nomeado como trabalho de propaganda, avaliado pelo comandante do movimento como "relativamente bom" (Grabois, 2014, p. 120). Sobre tal publicidade e o seu alcance, Fernando Portela comenta: "Nos versos de cordel, que eles mesmos inventavam, as novas ideias começavam a tomar conta das populações dos lugarejos do Araguaia: São Domingos, Santa Isabel, Palestina, Bacaba, Metade, Brejo Grande, Bom Jesus, Porto Franco” (2002, p. 
78-79). Portela inicia o capítulo V, de seu livro Guerra de guerrilhas no Brasil: a saga do Araguaia, com os versos desse romance, que citamos a seguir:

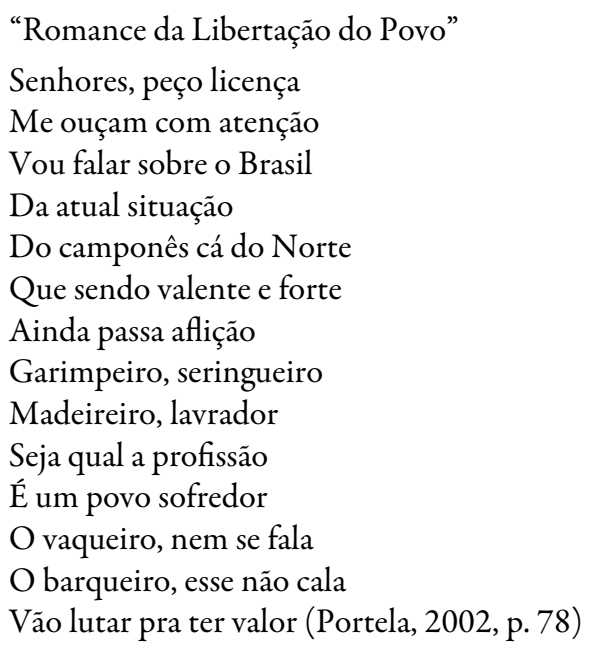

Os versos acima também foram inseridos em outra obra: A guerrilha do Araguaia -cordel documento, de R. Nonato da Rocha. Nela consta que "Bergson ${ }^{21}$ improvisou o Romance da Libertação" (Rocha, 1980; Monteiro, 2005, p. 180). No livro Diário da guerrilha do Araguaia - apresentado pelo sociólogo Clóvis Moura como um "documento, cuja autenticidade não pode ser contestada [porque] impressiona pelos detalhes fornecidos, por fatos e pormenores, dados da região, hábitos e costumes dos seus habitantes e de personagens que participaram da guerrilha"22 (Moura, Diário da guerrilha do Araguaia, 1985) -Bergson é apontado como autor de "A vida de um lavrador", folheto também decorado pela população local. Sobre o romance transcrito acima há a seguinte anotação: "O povo aprende rapidamente $\mathrm{O}$ romance da libertação, uma história contada em literatura de cordel sobre a vida da região. Bastante educativa. Contém mais de sessenta estrofes de sete versos [...]" e cita os mesmos versos, mas divididos em duas estrofes (Diário da guerrilha do Araguaia, 1985, pp. 53-54).

Uma versão mais completa desse romance está em Guerrilha do Araguaia, organizado por Adalberto Monteiro (2005). Uma breve apresentação informa que são apenas "alguns dos versos de um cordel” escrito por Mundico (Rosalindo Souza) ${ }^{23}$, integrante do movimento guerrilheiro "e que foi guardado de memória por um morador [de São João do Araguaia] que o conheceu, [...] José da Luz Filho" (Monteiro, 2005, p. 177). São seis septilhas, com versos livres, compostos por rimas externas, mistas (seguindo o esquema: ABCBDDB), consoantes, pobres e ricas, agudas e graves. Segue a transcrição apenas das estrofes ainda não citadas:

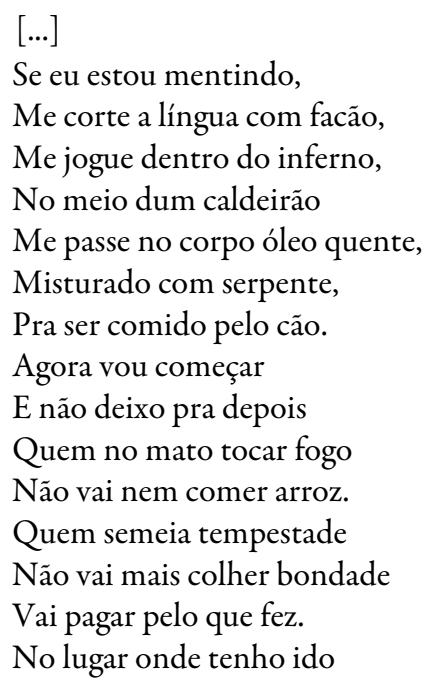


Tudo é grande e natural.

Tem minério na floresta,

Pra caçar tem até demais,

Tem terreno até largado,

Tem madeira, roça e gado,

Babaçu e castanhais.

Os viventes destas bandas

São escravos do patrão.

Só são pagos com bagulhos,

Quer o povo queira ou não.

No esforço do trabalho

Não lhe deixam escoar,

Então é grande a exploração.

[...] (Monteiro, 2005, p. 177)

Com algumas variações, trechos do mesmo romance aparecem em alguns relatos, como o registrado no jornal Resistência, em dezembro de 1980, quando familiares dos guerrilheiros percorreram a região onde ocorreu a Guerrilha do Araguaia e encontraram o mesmo morador (José da Luz Filho), que revelou mais detalhes sobre a sua amizade com Nelito (Nelson Lima Piauhy Dourado), Edson (Hélio Luís Navarro de Magalhães), Duda (Luiz René Silveira e Silva), Waldir (Uirassu de Assis Batista), Nilo (Danilo Carneiro), Zé Carlos (André Grabois), Sônia (Lucia Maria de Souza), Cristina (Jana Moroni Barroso) e todos os integrantes do Destacamento A e comentou sobre a "poesia de cordel" que eles escreveram. Recita quatro estrofes (das mesmas já citadas) com uma variação na última:

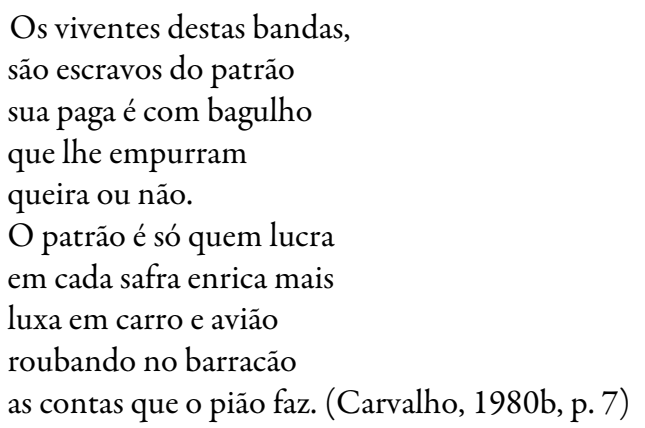

Contou ainda que pediu o texto aos guerrilheiros, copiou e gravou. No documentário "Camponeses do Araguaia: a guerrilha vista por dentro", Zé da Onça, morador da região também lembra de alguns fragmentos deste cordel. Informa que ganhou um caderno pequeno com o "Romance da Libertação", escrito de próprio punho por Nunes (Divino F. de Souza) ${ }^{24}$-porém o documento foi destruído quando o exército queimou a sua casa. $\mathrm{O}$ fragmento a seguir foi, na ocasião, recitado de memória pelo camponês:

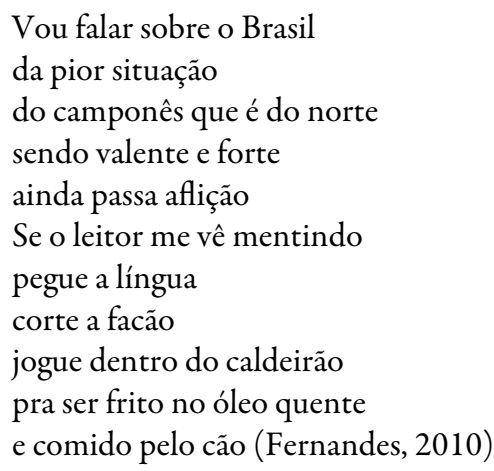


Em entrevista publicada no primeiro volume da coleção "História Imediata", José Genoino Neto (Geraldo) ${ }^{25}$ fala sobre a comemoração no final do ano de 1971 e em seguida cita a literatura de cordel utilizada pelo movimento:

[...] juntamos todo o destacamento [B - base Gameleira] na casa principal, na noite de 31. [...] havia três grupos! Cada um preparou um teatrinho. O nosso fez uma espécie de jogral [...]. Outro grupo fez um jogral tipo literatura de cordel, com o programa dos 27 pontos, e o outro apresentou como era a vida na mata. (Dória et al, 1978, p. 39, grifo nosso)

Também comenta sobre as músicas populares cantadas por eles, como "Apesar de você" "Viola Enluarada", e explica: "[eram] músicas que tinham relação com nossa vida de estudante” (Dória et al, 1978, p. 39). Outra música citada é "Pesadelo", uma composição de Maurício Tapajós e Paulo César Pinheiro. Este último revela em entrevista: "Contaram que durante a Guerrilha do Araguaia, na selva, eles [os guerrilheiros] cantavam Pesadelo. Dizem ter sido a música que mais ajudou, nessa fase de luta armada, a todos eles, a mais forte politicamente que a gente fez [...]" (Antero; Monteiro, 2005, p. 21, grifo do autor).

Sobre este evento de confraternização no final de 1971 há mais informações: "A confiança adquirida ao longo do ano [1971] animou o réveillon de 1972 na Gameleira. [...] Osvaldão recitou o poema I-Juca Pirama, de Gonçalves Dias, e todos cantaram 'Apesar de você', de Chico Buarque de Hollanda” (Gaspari, 2002, p. 412, grifo do autor) ${ }^{26}$; e "No fim do ano de 1971, os residentes no Gameleira organizaram uma festa de confraternização. [...] cantam canções de combate ou músicas de Chico Buarque, como Amanhã será outro dia. [...] à noite, [aconteceu] uma espécie de teatro de cordel." (Diário da Guerrilha do Araguaia, 1985, pp. 31-32).

Retomando os poemas observamos que alguns dele espelham a composição daqueles transcritos no Diário de Grabois. Isto reitera a hipótese de que tenham surgido na região onde ocorreram os confrontos e que, inicialmente eram utilizados como canções entoadas no próprio espaço de luta. Os textos publicados pelo jornal Resistência apresentam estruturas variadas como, por exemplo, "Cantar é preciso" que se apresenta ao modo da prosa poética, como se fosse um quadro narrativo; por sua vez, "Eh Marabá" apresenta uma estrutura apoiada na irregularidade, ou seja, é constituído por: uma estrofe irregular (13 versos), uma quadra, um monóstico, uma nona, uma quadra e um monóstico, todas com versos brancos e livres ${ }^{27}$.

Trata-se de uma literatura com características próprias. A liberdade almejada no conteúdo do material também está presente na própria forma das obras. São textos que, embora apresentem certas regras de estruturação, parecem seguir as próprias normas - ou não se submeter a nenhuma. Em um dos registros do Diário do comandante da guerrilha, o autor escreve: "Estou certo de que aqui, no Araguaia, se forjará uma autêntica literatura revolucionária e popular, com suas características próprias.” (Grabois, 2014, p. 112). Isto revela uma escrita ética, onde a maior preocupação não é cumprir as exigências estéticas, mas divulgar o movimento e seus objetivos. O autor do Diário explica a literatura da guerrilha: "Nem sempre a qualidade da produção literária é boa, mas seu conteúdo visa sempre exaltar o movimento guerrilheiro; torná-lo conhecido do povo" (Grabois, 2014, p. 112).

Há outros documentos indicados como escritos no cenário da luta ${ }^{28}$. As informações coletadas até o momento indicam que boa parte desse material é originária da experiência da guerrilha. Se comparados com a produção poética divulgada pelo Resistência observa-se características na forma e no conteúdo que, somadas, tem como objetivo principal chamar atenção para questões sociais e políticas. O material divulgado na região era utilizado tanto para efetuar denúncias sobre desmatamento, grilagem, exploração, injustiças, etc. como para fazer propaganda sobre os ideais revolucionários do movimento. A luta armada era contra o sistema opressor e a favor de uma vida melhor, onde todos tivessem "pão e instrução". O discurso utópico presente nestes documentos, também faz parte da produção poética da guerrilha. Entre os poemas publicados pelo jornal e o material registrado no Diário de Maurício Grabois há a mesma base: uma poética da resistência fundamentada no clamor para a luta ou o desafio à exploração e à expropriação, aspectos temáticos que podem estar presentes separadamente ou associados. 
Outro detalhe que chama atenção entre os documentos sobre a guerrilha é a aproximação entre o conteúdo do poema “escrito por um combatente. Seu autor é João. Pertence ao DB” (Grabois, 2014, p. 113) e a capa do folheto Primeiras Cantigas do Araguaia. Segue a transcrição dos versos:

12 de Abril

Desta vez ressoas longe

Um punho se ergueu

Um tiro foi o som que noite escutou

Os ouvidos de milhões buscam o rumo: o Sul do Pará

Nasceste forte, guerrilha

O sangue que te rega é dos melhores filhos

De um povo que sofre e luta

E segue teus passos atento, no Sul do Pará

A trilha que abres, bem larga

Tem rumo no futuro

Esperanças renascem

Faces pálidas sorriem

O horizonte desponta, no Sul do Pará

Teus heróis dizem da vida

Que carregas em ti

Da semente que nasceu

Fecundada pelo pensamento revolucionário do povo que representas

Que se apressa em vê-la crescer, no Sul do Pará

Mas há o que desespera

O opressor treme ante tua fúria

Tem séculos o seu medo

O futuro do povo é a cruz do seu túmulo

Sua primeira sepultura é o Sul do Pará

Guerrilha, és forte

Teu exemplo é o Norte, da Libertação

$\mathrm{Na}$ busca da vida

Representas a morte, da vil opressão

Teus passos caminham

Em busca da glória, que breve virá

Precisas seguir

Teu nome é Vitória, no Sul do Pará (Grabois, 2014, pp. 113-114) 
Figura 3 - Capa de Primeiras Cantigas do Araguaia

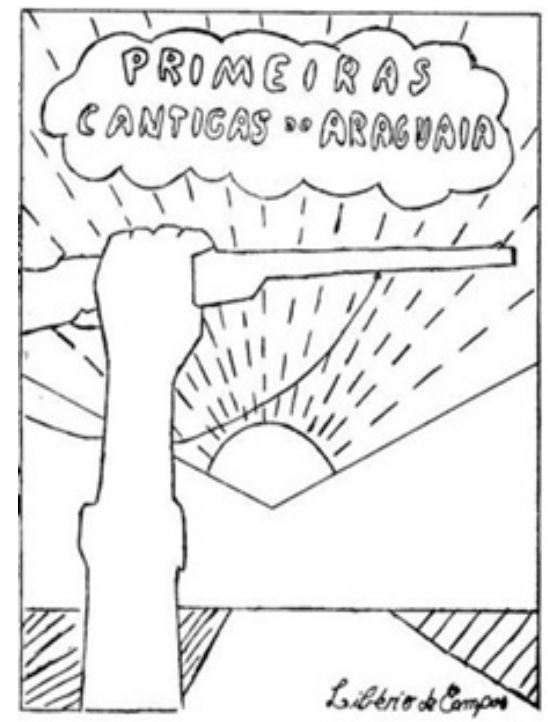

Fonte: Biblioteca Brasil Nunca Mais

A dimensão épica está, portanto, muito evidenciada nesses textos. O próprio contexto de produção desses escritos contribui para a imagem heroica, no sentido de que eram materiais utilizados com o intuito de não apenas reforçar o espírito de combate, mas ao mesmo tempo celebrar a luta dentro do espaço beligerante. Sobre esse aspecto o comandante da guerrilha escreveu: "Não me rendo, continuarei a ser sempre jovem, um revolucionário, um marxista-leninista. Não por acaso o comunismo é a juventude do mundo. Confio, com o mesmo ardor de moço, na vitória da revolução no Brasil.” (Grabois, 2014, p. 16). Presença evidente também nos hinos "Canção do Guerrilheiro do Araguaia" e "Lutar"; na prosa poética "Cantar é Preciso" dedicada "principalmente ao povo e às Forças Guerrilheiras do Araguaia, pela sua brava resistência patriótica, de onde já saltaram para a História verdadeiros mártires e heróis [...]" (Carvalho, 1979b, p. 24); no texto de "12 de Abril [...]”; e nos versos de "Poema para Helenira”, “Quelé29”, e "Maria Lucia ${ }^{30}$, jovem como nós" (Estes três últimos poemas não foram publicados pelo Resistência).

Apesar da impossibilidade de afirmar categoricamente a origem dos poemas de Primeiras Cantigas do Araguaia, pode-se, com base nos registros do comandante da guerrilha e em outras fontes apresentadas ao longo deste texto, dizer que há fortes indícios de que eles tenham surgido da experiência de campo dos guerrilheiros. Porém, trata-se de uma questão que precisa ser verificada mais detalhadamente através de outros estudos e pesquisas.

A seguir apresentamos a análise de dois poemas que fazem parte do corpus publicado no jornal Resistência: "Cantar é preciso" e "Eh, Marabá", a fim de mostrarmos de maneira mais detida os aspectos que correspondem à presença de traços épicos, que logram estar presentes em todo essa produção e que dialogam com a matéria relativa à guerrilha do Araguaia.

\section{CANTAR A RESISTÊNCIA É PRECISO, VIVER TAMbÉm (NEM QUE SEJA COMO MEMÓRIA)}

A primeira frase no capítulo "Narrativa e Resistência", de Alfredo Bosi (2002, p. 118) é: "Resistência é um conceito originalmente ético, e não estético". Ela está ligada à força de vontade no sentido de opor-se a forças externas. A arte, porém, estaria relacionada às potências do conhecimento e não de força de vontade. Neste sentido, "não se deveria misturar conceitos próprios da arte e conceitos próprios da ética e da política" (Bosi, 
2002, pp. 118-119). Mas, ele também nos oferece a solução ao dizer que é possível passar "da esfera ética para a estética" quando o autor explora os seus valores (força) que "repelem e combatem os antivalores respectivos" (2002, p. 120). Com vários exemplos Bosi chega às aproximações entre narrativa e resistência, identificando duas maneiras: resistência como tema; e resistência como processo imanente à escrita.

A primeira está relacionada a obras que representam o engajamento do autor contra determinada ideologia dominante (política ou filosófica, ou regime) posicionada historicamente. O "tema da resistência se universaliza na cultura existencialista. Confere uma dimensão ética a uma atitude que transcende a fato da oposição" (Bosi, 2002, p. 129). A escrita é: não conformista, revolucionária, de recusa. Trata-se da relação entre narrativa e resistência ética ocorrida em um âmbito com significado temporal, inserido na cultura de resistência política. $\mathrm{O}$ conflito não acontece dentro da personagem. Ela é provocada por determinado impulso externo que a motiva a desafiar ou resistir.

A segunda é sobre obras "escritas independentemente de qualquer cultura política militante" que mostre "uma tensão interna que as faz resistentes, enquanto escrita, e não só, ou não principalmente, enquanto tema” (Bosi, 2002. p. 129). O embate vai além do estilo e da mentalidade dominante. Basicamente a tensão ocorre em dois momentos: antes (a ideia, o motivo, a origem) e durante o próprio processo de escrita. Com relação à poesia o autor identificou as modalidades: a resistência da sátira e da paródia; a resistência profunda da poesia mítica; a resistência interiorizada da lírica (memória e imaginação enlaçadas); e a resistência que se faz projeto ou utopia no poema voltado para a dimensão do futuro. Assim define:

A poesia, forma auroral da cultura, está aquém da teoria e da ação ética, o que não significa, porém, que não possa conter em si a sua verdade, a sua moral; e sobretudo, o seu modo, figural e expressivo, de revelar a mentira da ideologia, a trampa do preconceito, as tentações do estereótipo. (Bosi, 2002, pp. 130-131).

Ao analisar poemas de resistência produzidos no âmbito da literatura francesa, entre 1940 e 1945 , produzidos no contexto da Segunda Guerra e na ofensiva dos Aliados contra o Nazismo, Yasmine Getz diz que a poesia de resistência depende da dimensão circunstancial de onde emerge. Argumenta ela que apesar de ser oriunda da fala individual do poeta trata-se de uma poesia interessada e ardente, que coloca a nação em relevo, comportando-se como se fosse uma canção nacional, capaz de carregar as esperanças e convicções populares do lugar de onde provém e/ou de uma determinada época. Com esse propósito estende a posição individual -do poeta- a um todo coletivo, nesse caso em particular às figurações do povo francês. Por outro lado, o coletivo também repercute e em alguns casos até mesmo justifica a matéria poética. Nesse tipo de poesia é ainda abolida a distinção entre poiesis e práxis e Ação e Sonho se confundem (Getz, 2000, p. 354).

Não sem razão, Cristiano Jutgla considera que a fortuna crítica sobre a poesia contemporânea produzida no Brasil tem consagrado determinadas tendências, como a poesia marginal e o concretismo, ao mesmo tempo em que negligencia a poesia política. Diz ele que a "[...] razão alegada para a atitude seria um suposto déficit expressivo, considerados esteticamente sem efeito sobre o leitor hodierno, porque os poemas foram feitos sob o calor da hora, ou seja, dependentes do contexto histórico" (Jutgla, 2013, p. 74). Contudo, nota ainda que

A produção poética de combate merece ser objeto de estudo tanto pela problematização estética que coloca, uma vez que sua configuração instaura uma revisão dos critérios de avaliação, justamente porque diversos textos de combate apresentam sintomaticamente um caráter testemunhal, por conseguinte, ético com os sobreviventes e, principalmente, com os mortos pelo regime militar. (Jutgla, 2013, p. 81).

Para além da tensão interna proposta por Bosi (2002) e da ênfase nas matérias de cunho coletivo, como salienta Gertz (2000), parece-nos que o teor testemunhal, tal como pontuado por Jutgla (2007) e também Wilberth Salgueiro (2010), é um aspecto evidente na poesia de resistência, bem como a linguagem da clausura ou sufoco, conforme salienta Nathália Macri Nahas (2017). Nos “poemas da Guerrilha do Araguaia” publicados no jornal Resistência é possível encontrar representados todos esses aspectos, além daqueles associados ao forte teor épico, conforme evidenciamos no tópico anterior, ao confrontarmos outros materiais 
com a mesma temática. A fim de dar vazão ao estudo de caso, como já indicamos, dentre os oito textos poéticos divulgados pelo periódico, selecionamos dois para análise: "Cantar é Preciso" e "Eh Marabá".

Quanto ao âmbito formal, o primeiro poema foi escrito em terceira pessoa e no folheto está dividido em duas partes, cada uma subintitulada com metade dos termos que compõem o título, "Cantar é/ Preciso" 31 . No jornal, o texto aparece publicado em duas colunas e o título centralizado, de forma que cada um dos termos fique sobre o seu fragmento. Além disso, o poema se apresenta ao modo da prosa poética, como se fosse um quadro narrativo. Segue a transcrição da primeira parte:

Cantar é

Um dia lembramos. Há quase dois anos, guerrilheiros no Araguaia. há quase dois anos, lutando. Contra a miséria. Contra a opressão. Contra o meio adverso, no meio da selva, lutando.

E a guerrilha vive. Lâmpada acesa na noite (há quase dois anos), vive. Apesar de insídias latifundiárias. Apesar dos tecnocratas. Dos belicosos. Dos trustes, dos monopólios. Apesar dos generais. Senhores da terra e da guerra, donos do fôgo[sic] e do lôgro[sic]. Apesar - e por causa deles - a guerrilha vive. E corre, como um regato noviço, para os rios da Manhã.

Vitórias foram conquistadas. Há quase dois anos, ali e além, cresce a resistência popular. O povo percebe. O povo aspira no ar um sopro de novo em tudo isso. E descobre. E se move. E resiste. E pouco a pouco se forja em coisa única, indizível.

E nós, que temos feito diante disso? Os que sabem o tempo não podem ficar à margem, assistindo apenas. Decerto que por fuzil e decreto é proibido cantar. Mas cantar é preciso. Quando ainda não o grito, seja o balbucio. Se não a palavra aberta, o amplo segredo. Nunca, no entanto, o silêncio. Dizem que o silêncio é de ouro. Mas de quem esse ouro? Sabemos que não só povo, para nós o silêncio é podre. E cantar é preciso. (Campos citado em Carvalho, 1979b, p. 24)

A matéria de cunho coletivo se manifesta e se justifica na presença da guerrilha e na luta nela implicada, mas, sobretudo, pelo tom épico da composição formal. A matéria coletiva é evidente desde a primeira estrofe do poema: Cantar é - na medida em que o parágrafo inicial se apresenta como memória das dificuldades encontradas pela guerrilha, desde seu início, e sobretudo na insistência em permanecer na luta: “Um dia lembramos. Há quase dois anos, guerrilheiros no Araguaia. Há quase dois anos, lutando. Contra a miséria. Contra a opressão. Contra o meio adverso, no meio da selva, lutando" (Campos citado em Carvalho, 1979b, p. 24).

O teor testemunhal marca presença na voz poética, na medida em que esta está constituída como coletivo guerrilheiro e no apelo à possibilidade de, com base nessa experiência, construir uma memória individual e coletiva -da qual o texto poético é o veículo- é requisitada para mostrar o passado de luta e resistência apesar das dificuldades. Essa resistência também é exaltada no segundo parágrafo: "a guerrilha vive [...] Apesar dos tecnocratas. Dos belicosos. Dos trustes, dos monopólios. Apesar dos generais. Senhores da terra e da guerra [...] Apesar - e por causa deles - a guerrilha vive”. Nesses termos, a memória vem agregar-se à sobrevivência, tema caro aos textos de teor testemunhal.

É justamente por causa dos "obstáculos" que se deve resistir com afinco, ainda que os guerrilheiros estejam em menor número em relação aos oponentes -como de fato estavam, uma vez que a superação dos inimigos depende justamente da capacidade de esquiva, até mais do que a força. Dois termos são manejados como alegorias dessas condições de resistência: o regato que, embora pequeno e de pouco volume, consegue esgueirar-se até os rios; e, a manhã, que tal como no famoso poema "Tecendo a manhã" (publicado em 1966), de João Cabral de Melo Neto, representa a possibilidade de um futuro. Desse modo, assim como "Um galo sozinho não tece uma manhã: / ele precisará sempre de outros galos", também em "Cantar é Preciso"esse futuro se encontra entrelaçado à ideia de construção em coletivo, em que a luta é ao mesmo tempo o tear e a tela em que todos poderão moldar o amanhã, ou seja, o futuro ou a transformação das condições do presente.

A presença da "manhã" ou mesmo do "amanhã" nesse poema cintila outra importante relação intertextual associada à repetição rítmica do termo "apesar”. Nesse sentido, essa repetição evoca ainda a intertextualidade com a canção "Apesar de você", de Chico Buarque, escrita em 1970. A letra de "Apesar de você", em sua camada mais superficial, é composta como se fosse uma simples briga de um casal de namorados em que um dos parceiros é acusado de admoestar o outro, mas na verdade é uma crítica à censura e as arbitrariedades do regime contra a liberdade de expressão, em que as estrofes do refrão, “Apesar de você/amanhã há de ser/ 
outro dia”, também constituem evocações à esperança de um futuro transformado pelas ações do presente, marcado por inúmeras formas de violência.

A linguagem da clausura ou do sufoco vem à tona em "Cantar é Preciso" através da associação entre a luta dos guerrilheiros e a crítica ao presente, que se estende para outros setores associados à governabilidade autoritária, trata-se dos outros "senhores da guerra", especialmente envolvidos na exploração e expropriação dos segmentos populares - trabalhadores nas cidades, mas, sobretudo, os camponeses, os ribeirinhos, os indígenas, que vivem no campo e dele tiram seu sustento- com quem os guerrilheiros se envolveram diretamente. É desse teor fortemente crítico que surge aquela tensão indicada por Bosi. Tensão inconciliável, no âmbito dos poemas da guerrilha.

No terceiro parágrafo o êxito é cantado porque o povo apoia o movimento. Os perigos são certos, mas é necessário continuar na luta: "Decerto que por fuzil e decreto é proibido cantar. Mas cantar é preciso. Quando ainda não o grito, seja o balbucio [...] Nunca, no entanto, o silêncio. Dizem que o silêncio é de ouro. Mas de quem esse ouro? Sabemos que não é do povo" (Campos citado em Carvalho, 1979b, p. 24). Nesta primeira parte a epicidade destaca-se, na medida em que a voz coletiva ganha importância, pois mesmo fraca deve ser insistente, repetitiva como uma canção, um refrão, porque o redizer ajuda a não esquecer. Assim, cantar é ter voz e a permanência da voz é memória, portanto, cantar é também sobreviver de alguma forma. Mas o canto e seu gesto, o "cantar", também equivalem a importância fundamental da palavra como expressão de uma linguagem da resistência, e, igualmente, da palavra como forma de luta não desjungida do direito à manifestação, à liberdade. Nesse processo, o canto equivale ao clamor pela luta.

A segunda parte, introduzida através do termo Preciso é como uma afirmação da necessidade pessoal e coletiva de resistir. Contém a justificativa da resistência (também) pela escrita, ao mesmo tempo em que manifesta as esperanças e as ações do grupo. Vejamos o excerto correspondente à segunda parte:

Preciso

Pensando nisso é que organizamos este caderninho. Revelação artística é talvez o que de menos se mostre aqui. Tampouco é áspero o canto conforme pede o momento. Guiou-nos porém, mais que tudo, a vontade de dizer. O desejo de quebrar as vidraças do silêncio.

Esperamos que esta nossa iniciativa - apenas débil sussurro - possa, de outros lábios, desentranhar, mais firmes, afirmações de esperança, cantigas de alvorecer. É, numa livre reação em cadeia, que as palavras se lavrem, se elevem, se multipliquem.

Este trabalho é, pois, dedicado a todo o povo brasileiro; a todos os que, de alguma forma, se batem pela liberdade; e principalmente ao povo e às Forças Guerrilheiras do Araguaia, pela sua brava resistência patriótica, de onde já saltaram para a História verdadeiros mártires e heróis, a exemplo de Bergson Gurjão, Quelé e Helenira Machado. (Campos citado em Carvalho, 1979b, p. 24)

O próprio título sugere dois significados: $1^{\circ}$ ) Se complementar a primeira parte do título (Cantar é) "preciso" aparece como adjetivo, ou seja, "Cantar é necessário", "Cantar é exato". Novamente, temos nesse trecho a presença da intertextualidade a direcionar relações capilosas com textos anteriores, bastante conhecidos, que da mesma forma refletem sobre a entrega do indivíduo a algo que é maior do que si mesmo, como o poema "Palavras de Pórtico", de Fernando Pessoa, e, "Os Argonautas", canção de Caetano Veloso, lançada em 1969, textos que dialogam entre si (Fiorin, 2008).

Pessoa inicia seu poema com uma citação: "Navegar é preciso, viver não é preciso", frase que ele vai buscar a Pompeu, um general romano que viveu entre 106-48 a.C., que por sua vez a proferiu para encorajar seus soldados, temerosos de embarcar em um navio rumo à batalha, no meio de uma grande tempestade. Assim a frase "Navigare necesse; vivere non est necesse" é apreendida por Pessoa, que a recria transformando-a em "Viver não é necessário; o que é necessário é criar" (grifo nosso), ao mesmo tempo em que assume a criação como ofício e postura para a vida (Fiorin, 2008). A busca por uma postura que seja um traço distintivo para a existência também se faz presente na canção de Veloso, uma vez que em “Os Argonautas navegar" -enquanto busca incansável- é o alimento para a vida. Esse traço distintivo que se coloca especialmente como disposição ou atitude é presentado em "Cantar é/ Preciso" pelo cantar, por isso o cantar é exato. O termo está presente no poema em dupla acepção: imprescindivel; preciso e também correto; adequado. Ora, se cantar equivale à 
permanência da luta enquanto memória e da resistência enquanto palavra, o canto é o traço distintivo de uma postura diante da vida e, ao mesmo tempo, o veículo dessa postura.

Se usado separado o termo "preciso" serve como a $1^{\text {a }}$ pessoa do singular do presente do indicativo -Eu preciso... seguido de outras condições necessárias: "dizer", "quebrar as vidraças do silêncio", "levar o meu canto a outros", "reverenciar meus companheiros". A justificativa no início deixa claro que a intenção é mais ética do que estética, desse modo, o poema é, sobretudo, mensagem, recado ou mesmo testemunho em escrita para os que ainda estão por vir: "Pensando nisso é que organizamos este caderninho. Revelação artística é talvez o que de menos se mostre aqui. Tampouco é áspero o canto conforme pede o momento. Guiou-nos porém, mais que tudo, a vontade de dizer. O desejo de quebrar as vidraças do silêncio". Temos aqui outra vez o desejo de que um "débil sussurro" ganhe ecos, ampliando-se até virar um grito -ou canto- coletivo, que vá além do presente fixado na batalha.

Essa associação entre a ideia de canto e coletividade, atrelada a um projeto ou utopia da luta, é um tema recorrente entre os "poemas da guerrilha da Araguaia" publicados pelo Resistência: "Canção das Forças Guerrilheiras do Araguaia"; "Canto de amor aos guerrilheiros do Araguaia"; e "O início”. Essa vontade de coletividade lembra que: "Uma das marcas mais constantes da poesia aberta para o futuro é a coralidade. O discurso da utopia é comunitário, comunicante, comunista. O poema assume o destino dos oprimidos no registro da sua voz", pois "o coro atua, necessariamente, [como] um modo de existência plural. São as classes, os estratos, os grupos de uma formação histórica que se dizem no tu, no vós, no nós de todo poema abertamente político". Porém, "o coro não se limita a evocar uma consciência de comunidade; ele pode também provocá-la, criando nas vozes que o compõem o sentimento de um destino comum” (Bosi, 1977, pp. 181-182).

A ideia de coro remete a coletividade e no futuro é isso que contribui para a construção de determinado acontecimento ou período. Maurice Halbwachs explica que a memória individual "não está inteiramente isolada e fechada. Um homem, para evocar seu próprio passado, tem frequentemente necessidade de fazer apelo às lembranças dos outros. Ele se reporta a pontos de referência que existem fora dele, e que são fixados pela sociedade" (1990, p. 54). Por esse motivo, o poema finaliza referenciando "verdadeiros mártires e heróis, a exemplo de Bergson Gurjão, Quelé e Helenira”.

Ao falar sobre testemunho Márcio Seligmann-Silva diz que o conceito de mártir está próximo à acepção de sobrevivente, aquele "que atravessou uma provação" - "Martyros em grego significa justamente testemunha”-, ou seja, a "acepção de testemunho como sobrevivente e como mártir indica a categoria excepcional do 'real' que o testemunho tenta dar conta a posteriori" (2003. p. 374). As três pessoas (Bergson Gurjão Farias - Jorge, Kleber Lemos da Silva - Quelé e Helenira Rezende de Souza Nazareth - Fátima) permanecem como desaparecidas, e por isso não podem dar seus testemunhos, mas as vozes no texto apresentam um teor testemunhal referente aos ideais dos guerrilheiros. "Cantar" é "preciso" apesar de tudo; cantar os ideais, a memória, o passado, a luta, as dificuldades, a guerrilha, as vitórias, a resistência e repeti-los sempre, de tal maneira, que o poema torna-se inegavelmente um texto com teor testemunhal e uma produção em homenagem aos guerrilheiros que pereceram.

O segundo poema que destacamos intitula-se "Eh Marabá”. Inicialmente, Marabá, cidade localizada nas proximidades de onde ocorreu a guerrilha é apresentada como um ponto de referência, um norte, uma bússola ou carta de orientação. Tal como nos poemas "O finado Joaquim" e "Poema do soldado morto", há em "Eh Marabá" uma acentuada integração entre o tema da guerrilha e a luta por justiça social, com destaque para o cenário urbano.

Pode ser que Marabá tenha sido escolhida para representar todas as cidades da região onde ocorreu a guerrilha, ainda que os mapas mostrem que os embates aconteceram mais ao sul da região, próximo as cidades de São Geraldo e Xambioá -esta última, aliás, também título e objeto de um livro e de uma canção com temática semelhante. Vejamos o poema "Eh Marabá": 


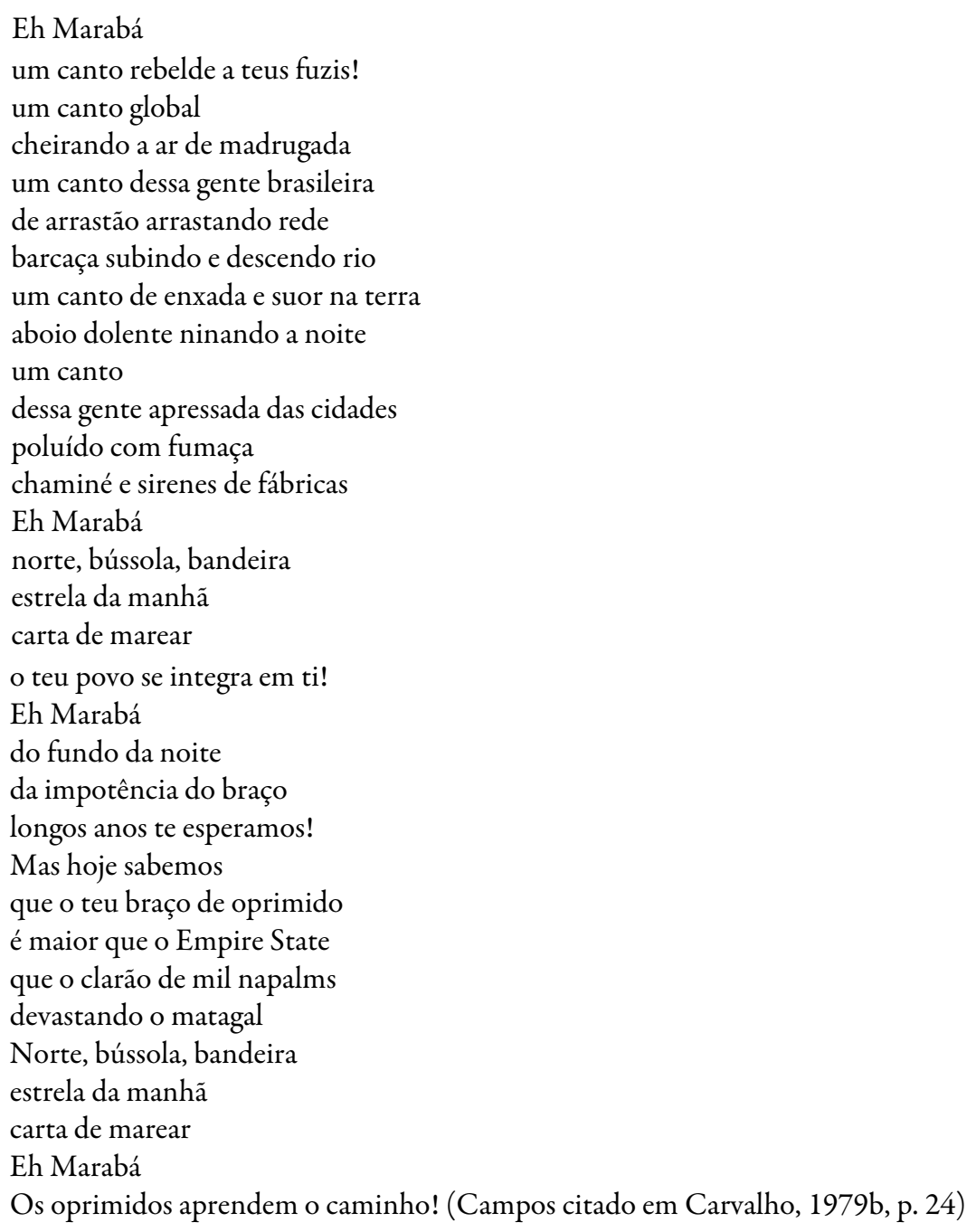

"Eh Marabá" organiza-se poeticamente como se fosse a letra de uma canção, dispondo de refrão. O poema também se desenvolve com base no argumento do canto como ponto de partida ou mesmo representação de uma coletividade, apresentando-se como música aos fuzis da cidade. Desse modo, temos o "canto" na primeira estrofe como um grito de angustia: "um canto rebelde a teus fuzis!" (como forma de dizer "não" à opressão); um canto global (de todos - a força do coletivo); um canto dessa gente brasileira (como união e identidade); um canto de enxada e suor na terra (e com isto fixa relações emblemáticas com os problemas agrários); um canto que reforça o apelo ou o protesto. Portanto, mais uma vez temos a presença do canto como metáfora do clamor.

O poema, então, evolui da canção ao grito: há um povo que grita. Esse povo que grita precisa de uma direção: Norte, bússola, bandeira -para seguir lutando. Marabá parece assim ser o lugar de trânsito daqueles que estão na luta pela sobrevivência comunitária e também ponto de chegada e partida daqueles que embarcam na luta armada -ainda que as referências a tal embate não sejam tão acentuadas, bem como é o objeto a quem se destina o "canto global", que é o corpo do poema.

Historicamente, Marabá foi um lugar estratégico para a luta armada, tanto para os guerrilheiros quanto para o braço repressor. É lá que se localiza a "Casa Azul”, prédio do Departamento Nacional de Estradas de Rodagem (DNER) que passou a ser base militar e centro clandestino de detenção de prisioneiros políticos. É em Marabá que circulam, ainda que em medrosos sussurros os relatos de confrontos e mortes de guerrilheiros e soldados e as notícias sobre corpos de guerrilheiros com cabeças decapitadas ("Pum-pum, tá-tá-tá-rá-rá-rá: Índios Suruí [...]”, 1978, p. 14).

Desse modo, assim como "Cantar é Preciso" também neste poema notamos a associação entre os signos da guerrilha e os signos que marcam a população oprimida -afinal, é nela que estão os fuzis, aos quais o canto 
é dedicado, mas em "Eh Marabá" a resistência à exploração ganha mais ênfase do que a resistência ao regime ditatorial. Por conseguinte, as referências a "gente brasileira" assentam-se sobre as camadas mais humildes e sofridas da população. Essa gente é quem deve entoar o canto: ora são os pescadores e camponeses, ora são os trabalhadores urbanos, a "gente apressada das cidades". Esse canto é ainda ora global, ora "poluído com fumaça/chaminé e sirenes de fábricas". Ao envolver todos nessa cantiga o poema mais uma vez fixa-se na busca pela integração de um coletivo, com agruras em comum e, portanto, com lutas em comum -"o teu povo se integra em ti!".

Essa integração, que dá a toda essa gente um sentido de pertencimento, é também fortemente movida por outro traço identitário de cariz social: a opressão. Na composição esse argumento ganha contornos poéticos incomuns ao manusear uma imagem prosopopeica atípica - "o teu braço de oprimido é maior que o Empire State" (grifos nossos), bem como a símile e comparação, ao estabelecer o tamanho desse braço à altura do famoso arranha-céu de 102 andares, localizado no centro de Manhattan, em Nova York. Ao fazer essas aproximaçóes o poema consegue estabelecer um interessante jogo opositivo entre quem representa essa gente e o que representa o Empire State enquanto monumento de poder econômico, símbolo dos valores americanos e do capitalismo global. Especialmente por que antes da chamada ao canto esse mesmo braço é um "braço impotente". É o canto de toda essa gente, portanto, que o torna forte e destemido, qualidades do bom povo guerreiro.

A rede de significações, atrelada ao dado material, também intertextualiza com a historiografia ao trazer ao texto o napalm, cuja referência mais conhecida provém de seu uso na guerra do Vietnã. Porém, em novembro de 1970 o Exército brasileiro utiliza o napalm contra guerrilheiros e posseiros, no Araguaia (Teles, 2014). Por esse motivo, os "mil claróes de napalm" se encontram ao lado do Empire State -poder econômico e poder repressivo emparelhados, completando o circuito da violência e da exploração, contra os quais o poema se direciona enquanto libelo do desafio e da luta.

\section{Conclusão}

Em função das temáticas envolvidas e também em razão de fazerem presentes os elementos estruturantes da poesia de resistência, os dois poemas analisados podem ser considerados como afins ao quadro mais amplo desse paradigma. Destacamos, como resultados da análise, a presença irrefutável do sentido de união e de coletividade, da tensão, do teor testemunhal e da linguagem e temática do sufoco, características que tem sido consenso entre os estudiosos da poesia de resistência. Contudo, destacamos especificamente no conjunto analisado a fixação na matéria épica, direcionada à história da guerrilha, bem como a presença marcante de um projeto ou utopia direcionada à justiça social e, portanto, o registro de um presente em que se faz saliente o apelo à intervenção transformadora da vida.

Notadamente voltados à escrita sobre a Guerrilha do Araguaia, nos dois poemas selecionados para o estudo de caso, observamos -assim como nos demais materiais do conjunto- que apresentam harmonia entre a organização formal e os argumentos desenvolvidos. Neles, o destaque sem dúvida reside no esforço envolvendo a ideia de escrita enquanto canto, ao mesmo tempo em que corporifica o canto enquanto chamado ou clamor à luta, o que faz desses poemas uma poesia de apelo combativo, em que a defesa da luta em favor de uma vida justa é seu principal argumento.

\section{REFERÊNCIAS}

A guerrilha do Araguaia. História da Guerrilha do Araguaia. (agosto de 1978). Resistência, 5, pp. 9-14.

Bertolino, O. (2011). Maurício Grabois e os devaneios de um jornalista. Vermelho. Recuperado de: https://vermelho .org.br/2011/04/22/bertolino-mauricio-grabois-e-os-devaneios-de-um-jornalista/

Carvalho, L. (fevereiro de 1979a). Exclusivo. Resistência, 9, p. 24. 
Carvalho, L. (fevereiro de 1979b). Os poemas da guerrilha do Araguaia. Resistência, 9, p. 24.

Carvalho, L. (julho de 1979c). Nota aos leitores. Resistência, 10, p. 2.

Carvalho, L. (abril de 1980a). Guerrilha do Araguaia: Granada do Exército mata e mutila lavradores. Resistência, Ano II, 11, pp. 18-19.

Carvalho, L. (dezembro de 1980b). Na trilha do "povo da mata”. Resistência, Ano III, 19, pp. 5-8.

Bosi, A. (1977). O ser e o tempo da poesia. (pp. 181-182). São Paulo: Cultrix, Ed. Da Universidade de São Paulo.

Bosi, A. (2002). Narrativa e Resistência. In A. Bosi. Literatura e resistência. (pp. 118-135). São Paulo: Companhia das Letras.

Brasil (2009). Dossiê Ditadura: Mortos e Desaparecidos Políticosno Brasil(1964-1985). (pp. 403 e 520-521). São Paulo: Imprensa Oficial.

Brasil (2014). Comissão Nacional da Verdade. (pp. 714-715). Brasília: CNV.

Campos, L. (1980). Primeiras Cantigas do Araguaia (Folheto). Recuperado de: http://www.docvirt.com/docreader. net/DocReader.aspx?bib=BibliotBNM\&PagFis=21032\&Pesq=

Ceia, C. (2018). E-Dicionário de Termos Literários. Lisboa: NOVAFCSH. Recuperado de: https://edtl.fcsh.unl.pt/ encyclopedia/romance/

Diário da Guerrilha do Araguaia (1985). São Paulo: Editora Alfa-Omega.

Diário de Maurício Grabois na Guerrilha do Araguaia (2014). Fundação Maurício Grabois. Recuperado de: http://www.grabois.org.br/portal/especiais/136883-44738/2014-04-10/diario-de-mauricio-grabois-na-gu errilha-do-araguaia

Dória, P., Buarque, S., Carelli, V. e Sautchuk, J. (1978). A guerrilha do Araguaia. História Imediata. São Paulo: AlfaOmega.

Encontrem Jana! (fevereiro de 1979). Resistência, 9, pp. 18-19.

Familiares de mortos e desaparecidos na guerrilha do Araguaia (1980). Apresentação. In L. de Campos. Primeiras Cantigas do Araguaia. (p. 4). Centro Mineiro de Cultura Popular. Recuperado de: http://www.docvirt.com/d ocreader.net/DocReader.aspx?bib=BibliotBNM\&PagFis=21032\&Pesq=

Fernandes, V. (Direção). Oka Comunicações (Produção). (2010). Camponeses do Araguaia: a guerrilha vista por dentro. [Documentário (73 min.), son., color]. CDM Centro de Documentação e Memória, Fundação Maurício Grabois. Vermelho. Recuperado de: https://vermelho.org.br/2013/10/15/camponeses-do-araguaia-a-guerrilha -vista-por-dentro/

Fiorin, R. P. (2008). A relação dialógica entre "Palavras de Pórticos" e "Os Argonautas". Travessias, 2(1). Recuperado de: http://e-revista.unioeste.br/index.php/travessias/article/view/2931

Gaspari, E. (2002). A floresta dos homens sem alma. In E. Gaspari. A ditadura escancarada. (399-464). São Paulo: Companhia das Letras.

Getz, Y. (2000). Poésie de la résistance, résistance du poete. French Forum, 25(3), 349-364. Recuperado de: https:// www.jstor.org/stable/40552152?seq=1

Halbwachs, M. (1990). A memória coletiva. (p. 54). São Paulo: Edições Vértice.

Jutgla, C. (2013). A Poesia de Resistência à Ditadura Militar (1964-1985): Algumas Reflexões. Elyra - Revista da Rede Internacional Lyracompoetics 2, 73-97. Recuperado de: https://www.elyra.org/index.php/elyra/article/view/27

Melo, I. (2018). Araguaia em verso e prosa: os poemas da guerrilha veiculados pelo Resistência (o jornal em defesa dos Direitos Humanos) (Dissertação de mestrado). UFPA, Belém.

Monteiro, A. (Org.) (2005). Guerrilha do Araguaia. São Paulo: Editora Anita Garibaldi.

Morais, T. e Silva, E. (2012). Operação Araguaia:os arquivos secretos da guerrilha. São Paulo: Geração Editorial.

Nahas, N. M. (2017). O confinamento em Grades: a poesia como resistência. Nau Literária, 13(1), 71-84. Recuperado de: https://seer.ufrgs.br/NauLiteraria/article/view/75461/46906

Neto, J. (setembro de 1978). A guerrilha do Araguaia. Resistência, 6, p. 23.

Nossa, L. (2012). Mata!: o Major Curió e as guerrilhas no Araguaia. São Paulo: Companhia das Letras. 
O que foi, afinal, a guerrilha do Araguaia (novembro de 1979). Resistência, 3, pp. 10-11.

Paraenses torturados. (agosto de 1978). Resistência, 5, pp. 16-25.

Por que tanto segredo? (agosto de 1978). Resistência, 5, p. 13.

Portela, F. (2002). Guerra de guerrilhas no Brasil: a saga do Araguaia. (pp. 78-79). São Paulo: Editora Terceiro Nome. Pum-pum, tá-tá-tá-rá-rá-rá: Índios Suruí, batedores do Exército, narram a guerrilha. (agosto de 1978). Resistência, 5 , p. 14.

Sá, G. (2004). Araguaia: relato de um guerrilheiro. São Paulo: Anita Garibaldi.

Salgueiro, W. (2007). Lira à brasileira: erótica, poética, politica. Vitória: Edufes.

Salgueiro, W. (2010). A poesia brasileira como testemunho da história (rastros de dor, traços de humor): a exemplo de Chacal. Texto poético 9. Recuperado de: https://issuu.com/textopoetico/docs/rev-textopoetico-v9-2010

Savino, A. (1973). Forma e conteúdo na poesia de Cecília Meireles. Curriculum, 12 (1), 9-22. Recuperado de: http:// bibliotecadigital.fgv.br/ojs/index.php/curriculum/article/view/62345/60470

SDDH (1977). O Estatuto da SDDH. Resistência, 0, p. avulsa.

Seligmann-Silva, M. (2003). O testemunho: entre a ficção e o “real”. In M. Seligmann-Silva (Org). História, Memória, Literatura: o testemunho na era das catástrofes. (pp. 371-385). Campinas: Editora da Unicampi.

Studart, H. (2006). A lei da selva. São Paulo: Geração Editorial.

Teles, J. A. (2014). Os segredos e os mitos sobre a Guerrilha do Araguaia (1972-1974). História Unisinos, $18(3), 467$. Recuperado de:

Vital, J. (16 a 31 de maio de 1983). A volta do ex-guerrilheiro ao Araguaia, 11 anos depois. Resistência, Ano VI, 55, p. 13.

\section{Notas}

1 Estatuto da SDDH publicado no jornal Resistência $\mathrm{n}^{\circ}$ 0, em fevereiro de 1978.

2 Para mais informações sobre o jornal ver Ivania Melo (2018). Araguaia em verso e prosa: os poemas da guerrilha veiculados pelo Resistência (o jornal em defesa dos Direitos Humanos) (Dissertação de mestrado).

3 Matéria publicada com o título "Paraenses torturados".

4 O Mapa guerrilha do Araguaia (1972-1974), in: Guerrilha do Araguaia: Uma epopeia pela liberdade (2005) informa que as Forças Armadas mobilizaram: na $1^{\text {a }}$ campanha - 5 mil homens; na $2^{\text {a }}$ campanha - de 8 a 10 mil homens; e na $3^{\text {a }}$ campanha - de 5 a 6 mil homens.

5 Era integrante do Destacamento A e está desaparecida desde 29 de setembro de 1972. (Dossiê Ditadura, 2009, p. 375).

6 Era integrante do Destacamento C e da Comissão Militar e está desaparecido desde 30 de setembro de 1972. (Dossiê Ditadura, 2009, p. 378).

7 Também “Canção das F. G. A.” como no folheto Primeiras Cantigas do Araguaia (Campos, 1974, pp. 38-39).

8 Para verificar a apresentação dos poemas e de outras obras publicadas pelo jornal Resistência ("Poesia popular"; "Hino do agricultor"; "A voz do povo"; "Amigos e companheiros [...]"; "Ciranda dos bairros"; "Na primeira noite [...]"; "Espelho da realidade"; e "Vida de pobre") ver Ivania Melo (2018). Araguaia em verso e prosa: os poemas da guerrilha veiculados pelo Resistência (o jornal em defesa dos Direitos Humanos) (Dissertação de mestrado).

9 Documento também publicado pela revista CartaCapital, em 21 de abril 2011. Ainda não há documentação histórica que ateste a existência do diário do comandante da guerrilha, tornando os dados imprecisos. Por esta razão seguimos a posição de Nossa que prefere ver o material como "suposto diário".

10 FGA - Organização criada em decorrência das operações militares que iniciaram em abril de 1972 “a fim de desbaratar as operações militares da ditadura, defender suas vidas e desenvolver sua luta pela posse da terra, a liberdade e uma existência melhor para toda a população [...]", Comunicado No 1, de 08 de junho de 1972. in: Diário de Maurício Grabois na Guerrilha do Araguaia, p. 13.

11 Um dos oito "poemas da guerrilha do Araguaia" publicados pelo Resistência, tem: oito quadras com versos brancos e livres, variando entre 4 a 9 sílabas métricas. A variação de sílabas nos versos também sugere o rompimento com a uniformidade métrica, rejeitando as regras de padronização e passando a ser uma escrita “subversiva”. Seu conteúdo está mais voltado à resistência armada.

12 Um dos oito "poemas da guerrilha do Araguaia" publicados pelo Resistência. Está dividido em duas partes: a primeira é formada por quatro tercetos com versos brancos e livres, variando entre 1 a 6 sílabas métricas; a segunda por duas quadras e três dísticos. Por apresentar variação de sílabas, pode-se utilizar a mesma explicação da nota anterior sobre 
escrita "subversiva". Seu conteúdo separado em duas partes sugere uma conversa, como se os tercetos fossem palavras de agradecimento e incentivo de pessoas externas à guerrilha: “[...] nas vossas mãos / não tendes fuzis”, "tendes clarões / estrelas / pedaços de manhã”, "nós vos amamos”. O segundo momento é como a resposta que inicia: "nós vos amamos / - que é preciso / o mais cedo / madrugar", "mas rompa-se / a distância / este nós-e-vós / que nos parte em dois”, são fragmentos que sugerem um agir sem demora, com união, inclusive do próprio poema para que todos lutem porque "a ordem é lutar".

13 Documento apreendido pela $33^{a}$ Brigada de Infantaria. (Morais e Silva, 2012, p. 269). Integrante do Destacamento B está desaparecido desde o dia 30 de setembro de 1972. (Dossiê Ditadura, 2009, p. 378).

14 Finaliza a carta da seguinte forma: “- 'Foguera' [sic] que não se apaga - Forças Guerrilheiras do Araguaia” (Morais e Silva, 2012, p. 621).

15 "O mais velho dos três irmãos guerrilheiros [Jaime e Maria Lúcia], gostava de estudar línguas e recitar poesias" (Morais e Silva, 2012, p. 575). Era Vice-comandante do Destacamento A e está desaparecido desde 14 de janeiro de 1974. (Dossiê Ditadura, 2009, p. 567).

16 Religião local. (Monteiro, 2005, p. 169).

17 Era o Comandante do Destacamento B, desapareceu em abril de 1974. (Dossiê Ditadura, 2009, p. 572).

18 "Participou da Guerrilha juntamente com o pai. Preso pelo Exército cumpriu serviço militar". (Campos Filho, 2012, p. 343).

19 Segundo o dicionário, "Romance" é a: "Designação usada na história da literatura portuguesa e galega para um tipo de poema épico breve, destinado ao canto, transmitido e reelaborado por tradição oral, que corresponde, no âmbito peninsular, à balada europeia, e de que se conserva um conjunto de exemplares no chamado Romanceiro." (Nunes, 2009; Ceia, 2018).

20 Trata-se de literatura de cordel, gênero bem aceito na região utilizado para chamar a atenção para os problemas locais e exaltação da luta. Os versos de R. Nonato da Rocha resumem o que era o "Romance da Libertação" naquele contexto: "poesia popular / mostrando a opressão / a terra e a disputa / um chamado para a luta / a toda a população". (Rocha; Monteiro, 2005, p. 180).

21 Bergson Gurjão Farias (Jorge) pertencia ao Destacamento C, está desaparecido desde 8 de maio de 1972. (Dossiê Ditadura, 2009, p. 343).

22 O documento foi entregue por "um dirigente do PC do B posteriormente morto" (Moura, 1985, XIII). Diz que é "um depoimento de dentro da guerrilha". Trata-se de "um documento redigido pelos participantes e dirigentes do movimento conhecido como 'Guerrilha do Araguaia”'. (Moura, 1985, p. XII, grifo do autor).

23 Em 1971 mudou-se para o sudeste do Pará. Também atribuíram a ele a autoria de outro cordel: "gostava de fazer cordéis, sendo de sua autoria um que fala dos 27 pontos defendidos pelos guerrilheiros. Esse cordel era recitado pelos camponeses da região." (Monteiro, 2005, p. 165; Dossiê Ditadura, 2009, p. 451).

24 Integrante do Destacamento A. Desaparecido desde 14 de outubro de 1973. (Dossiê Ditadura, 2009, p. 472)

25 A partir de 1970 residiu na localidade de Gameleira, (área do Destacamento B), onde permaneceu até 1972 quando foi preso. (Dória, Buarque, Carelli e Sautchuk, 1978, p. 27).

26 Ver também Glênio Sá (2004), Araguaia: relato de um guerrilheiro, p. 12.

27 No folheto Primeiras Cantigas do Araguaia o poema é formado por: um dístico, uma estrofe irregular (11 versos), uma quadra, um monóstico, uma nona, uma quadra e um monóstico (1980, p. 23).

28 São: "Programa dos 27 pontos"; "Regulamento das Forças Guerrilheiras do Araguaia”; "Comunicado nº 1 das Forças Guerrilheiras do Araguaia"; "Carta a um deputado federal"; "Comunicado no 5 das Forças Guerrilheiras do Araguaia”; "Comunicado no 6 das Forças Guerrilheiras do Araguaia”; "Comunicado do $3^{\circ}$ destacamento sobre a punição ao grileiro Nemer Curi"; "Manifesto à população no $1^{\circ}$ aniversário da resistência armada"; "Comunicado do destacamento Helenira Resende sobre o ataque um posto da polícia militar"; "Carta de quatro guerrilheiros ao bispo de Marabá"; "Carta aos amigos e conhecidos de Porto Franco, Tocantinópolis e Estreito"; "Comunicado n 8 das Forças Guerrilheiras do Araguaia"; "Carta de Guilherme Lund a seus pais"; "Cartas de Gilberto Olimpio Maria para sua esposa Vitória Grabois” (Monteiro, 2005, pp. 129-152).

29 Kleber Lemos da Silva era integrante do Destacamento B. Desaparecido desde 29 de junho de 1972. (Dossiê Ditadura, 2009, p. 356).

30 Mara Lúcia Petit da Silva era integrante do Destacamento C. Desapareceu em 16 de junho de 1972. Seus irmãos Jaime e Lúcio também faziam parte do movimento e despareceram na região da guerrilha do Araguaia. Ela foi a primeira "entre os desaparecidos da Guerrilha do Araguaia” a ter seus restos mortais identificados. (Dossiê Ditadura, 2009, p. 353).

31 A adoção da barra no meio do título foi iniciativa nossa para evidenciar a separação das duas partes do poema. 